\title{
논문 2
}

\section{2}

[2012-12-WD-002]

\section{고전압 무효전력 보상기를 사용한 대규모 풍력발전 설비의 전력 품질 보상}

김지홍*, 송승호**, 정승기

\section{Control of Power Quality Using a High Voltage STATCOM for the Integration of Large Scale Wind Power Plant}

Jihong Kim*, Seungho Song** and Seunggi Jeong

Abstract This paper describes a transformerless static synchronous campensator (STATCOM) system based on cascade $\mathrm{H}$-bridge multilevel inverter with star configuration. It is designed not only for the dynamic and continuous compensation of the reactive power but also for the improvement of power quality of existing wind power plant. Especially, when the induction generator of wind turbine is directly connected to the grid, reactive power are occurred by exiting current. so a reactive power compensation system based on the cascade H-bridge multilevel STATCOM is proposed because the output power quality and controllability of reactive power are required by grid code in many different countries. Using various The proposed reactive power control strategy using a STATCOM is compared with the conventional scheme using fixed-size of capacitor bank through various simulation results.

(접수일 2012. 9. 24, 수정일 2012. 10. 9, 게재확정일 2012. 10. 9)

* 광운대학교 전기공학과 (Kwangwoon University / Dept. of Electirical Engineering)

— E-mail : ranpoo@kw.ac.kr — Tel : (02)940-5146 — Fax : (02)943-7195

** 광운대학교 전기공학과 (Kwangwoon University / Dept. of Electirical Engineering)

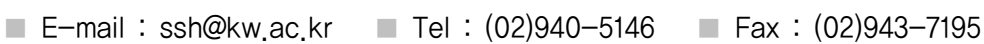

\section{Nomenclature}

$V_{s}:$ grid voltage, $V$

$I_{s} \quad$ : grid current, $A$

$I_{\text {cap }}$ : capacitor bank current, $A$

$V_{c}$ : cascade H-bridge STATCOM voltage, $V$

$I_{c} \quad$ : cascade H-bridge STATCOM current, A
$I_{G} \quad$ : induction generator current, $A$

$\overline{V d c}$ : average of dc-link voltage, $V$

$V_{d c a}$ : aPhase average of dc-link voltage, $V$

$V_{d c b}:$ bPhase average of dc-link voltage, $V$

$V_{d c c}:$ cPhase average of dc-link voltage, $V$ 


\section{1. 서 론}

최근 신재생 에너지에 의한 관심이 증가됨에 따라 특히 풍 력, 태양광 발전 시스템 등 계통연계형 신재생 발전 시스템의 설치가 크게 늘어나고 있다. 이에 따라 전력계통 운영자들은 시스템의 안정정과 전력의 품질을 유지하기 위해 전력계통 연계를 위한 기술기준, 즉 그리드 코드를 강화하고 있다 ${ }^{(1)}$. 풍력, 태양광등의 계통연계형 신재생 에너지 발전 장치는 기상의 변동에 따라 발전량이 급격하게 변동하더라도 출력전 압을 유지하고, 계통 전류를 안정적으로 유지시킬 수 있을 뿐 아니라, 부하에 양질의 전력을 공급하여야 한다.

특히, 유도발전기를 사용한 고정속도방식 풍력발전 시스템 에서 풍속의 변화에 따라 계통 투입, 분리를 반복할 때의 돌 입전류와 풍속의 변화에 따른 출력변동 등은 유효전력뿐만 아니라 무효전력의 변동으로 인해 주변 지역의 전압 변동이 발생하며 전구의 밝기가 출렁거리는 플리커의 요인이 된다. 따라서, 수시로 변동하는 유효전력에 따라 필요한 무효전력 을 주입하여야 한다 ${ }^{(2)}$.

고정속도 방식의 풍력발전시스템은 국내 뿐만 아니라 북미, 유럽 등에 다수 설치되어 운전중에 있으며 보통 여러대의 풍력 발전기가 하나의 단지 형태로 운영되고 있는 경우가 많다.

유도발전기는 여자전류를 공급하기 위해 항상 무효전력을 필요로 한다. 무효전력을 보상하기 위하여 풍력 발전기마다 설치된 커패시터 뱅크를 온, 오프하는 방식을 주로 사용하였 으나 무효전력량이 변동할 경우 고정된 커패시터로는 정확한 보상이 불가능하며 기계적인 접점 스위치를 사용하기 때문에 잦은 유지보수가 필요한 문제가 있었다.

따라서 강화되는 그리드 코드에 대응하고 우수한 품질의 출력 전력을 얻기 위하여 풍력발전 단지의 출력단에 정지형 무효전 력 보상장치(Static Synchronous Compensator, STATCOM)를 설치하는 사례가 늘고 있다. STATCOM은 전력반도체 스위 치를 이용하여 PWM방식으로 전원과 부하사이에서 필요한 무효전력을 공급하는 장치이며 최근 IGBT를 스위치로 사용 하면서 고조파 전류에 대한 보상까지 가능해 졌다.

최근에는 단위 풍력발전기의 용량이 증가할 뿐만 아니라 풍력발전 단지의 규모도 커지는 추세이므로 대용량 무효전력 보상이 가능한 멀티레벨 방식의 STATCOM이 필요하다. 다양 한 형태의 멀티레벨 인버터 토폴로지 중에서 STATCOM에 적
합한 것은 무엇일까? 클램핑 다이오드 방식은 전압레벨이 높 아질 경우 클램핑 다이오드의 수는 증가하며, 형태는 더 복잡 해지는 단점이 있어 실제적인 관점에서의 응용은 5 레벨까지 이다. 플라잉 커패시터 방식은 저주파 $(1 \mathrm{kHz}$ 보다 낮은 캐리어 주파수)에서 플라잉 커패시터의 가격이 비싼 단점이 있다 ${ }^{(3)}$.

본 연구에 제안된 풍력발전용 전력품질 보상장치는 Cascade $\mathrm{H}$-bridge 멀티레벨 인버터 방식을 사용하므로 클램핑 장치 가 필요하지 않고(e.g 다이오드 또는 커패시터) 1 개의 셀이 단상 인버터로 이루어진 구조이기 때문에 회로를 모듈화 할 수 있으며, 구조가 복잡하지 않을 뿐 아니라, 부피가 크고 가 격이 비싼 변압기가 없어도 된다는 장점이 있다 ${ }^{(4,5)}$.

본 논문에서는 Cascade H-bridge STATCOM을 소개하 고, 이에 대한 설계 기술을 설명하였다. 고정속도형 유도발전 시스템의 운전중 무효전력이 변동하는 상황을 모의하고 커패 시터 뱅크를 사용한 무효전력 보상과 STATCOM의 무효전력 보상을 PSIM 프로그램 개발환경에서 시뮬레이션 비교를 통 하여 검증하였다.

\section{Cascade H bridge STATCOM 구성}

\section{1 직렬 연결 수}

Cascade H-bridge의 각 상별 연결 수는 직류단 커패시터 의 전압과 관련이 있으며, $\mathrm{n}$ 개의 단상인버터 모듈이 연결되 어 있다고 할 때 한 상에서 출력은 $2 n+1$ 개의 출력이 나타난 다. 이 때, 직렬연결 수를 정하기 위해서 IGBT의 내압이 중요 한 선정요소이다. 근래에 합리적인 가격으로 구할 수 있는 $1.2 \mathrm{kv}$ 의 IGBT를 사용하고, 직류단 전압을 $1000 \mathrm{~V}$ 로 설계한 다면, 이 때 셀의 출력, 즉 단상 Full bridge 인버터의 교류 전압출력의 기본파는 (1)과 같다.

$$
\begin{aligned}
& V_{s r m \mathrm{~s}}=\frac{1}{\sqrt{2}} \cdot m_{a} \cdot V_{d c} \\
& 566 V=\frac{1}{\sqrt{2}} \cdot 0.8 \cdot 1000
\end{aligned}
$$

$\mathrm{ma}$ 는 크기변조비로서 1 보다 작을 경우 선형적으로 증가 하므로, 크기변조비를 0.8 로 설정한다면 한 개 셀의 기본파 
출력전압은 $566 \mathrm{~V}$ 되고, $3.3 \mathrm{kv}$ 의 수전설비에 연계된다고 하 면 위 수식으로부터 (2)를 통하여 셀의 직렬연결 수를 구할 수 있다.

$$
N=\frac{3300 \mathrm{~V}}{\sqrt{3} \cdot 566 \mathrm{~V}}=3.3
$$

(2)를 통하여 상별 셀의 직렬연결 수를 구할 수 있다.

\section{2 시스템의 구성}

Fig. 1은 변압기를 사용하지 않고 성형결선의 형태로 $3.3 \mathrm{kV}$ 수전설비에 직접 연계된 회로 배치이다. Cascade H-bridge $\mathrm{STATOM}$ 은 각 상별로 3 개의 셀이 연결되며, 각 셀에 분리된 직류단을 가지고 있다. 각 셀은 같은 크기의 직류단과 같은 정격의 $1.2 \mathrm{kV} \mathrm{IGBT}$ 를 사용하고, 직류단은 커패시터로 구성 되며, 커패시터의 용량 또한 같다.

각 상별로 3 개의 셀이 연결되었기 때문에 상과 중성점의 출력 전압레벨은 7 레벨이 되고, 선간출력 전압은 13 레벨이 된다.

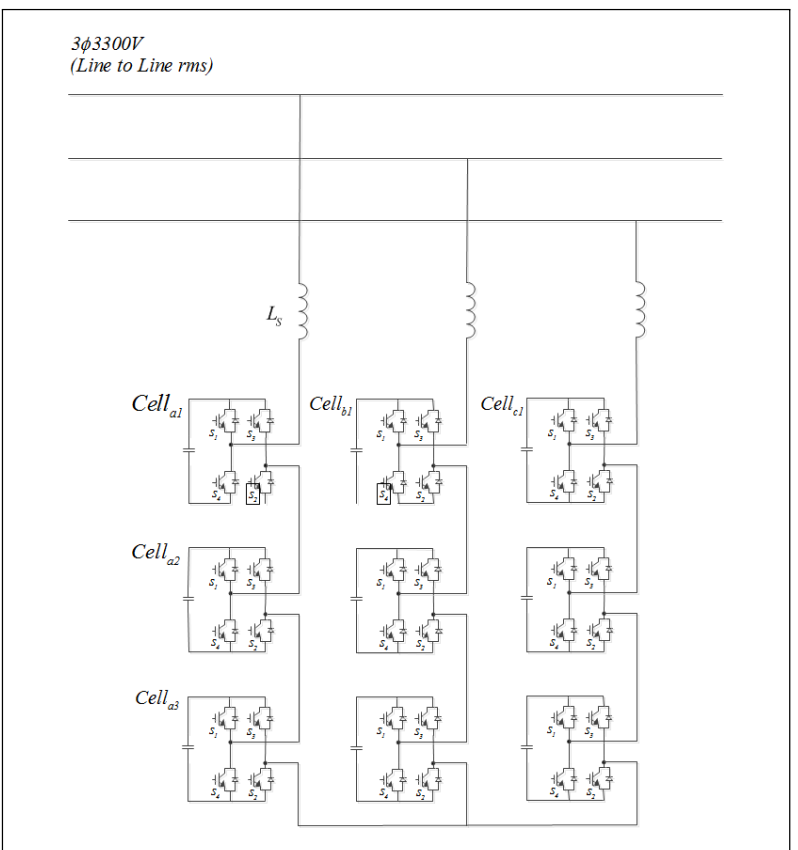

Fig. 1 Circuit configuration of the star-configured Cascade H-bridge STATCOM
멀티레벨의 여러 스위칭 방식 중 "Phase shifted unipolar $\mathrm{SPWM}$ "방식을 적용할 경우, 각각의 셀이 $1 \mathrm{kHZ}$ 의 스위칭을 할 경우 스위칭에 의한 고조파 성분은 $6 \mathrm{kHZ}$ 로 보이게 된다. Cascade H-bridge 멀티레벨 인버터의 고조파 성분이 기본파 차수 주파수 대역보다 더 높은 대역에 위치하게 될 뿐아니라, 개별 셀의 스위칭의 주파수는 높지 않다는 장점이 있다 ${ }^{(6)}$.

STATCOM의 출력 측에 설치된 인덕터(Ls)는 계통과 STATCOM 을 연계시키는 역할을 하며, PWM에 의해 생기는 스위칭 리 플을 필터링한다.

\section{STATCOM을 이용한 풍력발전시스 템의 출력 품질 보상}

\section{1 고정 속도형 풍력발전기}

Fig. 2는 고정 속도형 풍력발전시스템의 구성도이며 블레 이드에서 발생된 운동에너지가 기어박스를 거쳐 유도 발전기 를 통해 전기에너지로 변환되어 전력계통에 직접 연계된다. 고정 속도형 풍력발전기의 경우 전력변환을 해줄 수 있는 인버 터가 없이 직접 계통에 연계되기 때문에 유도발전기에 여자 전 류를 공급하기 위해 무효전력을 보상해줄 외부회로가 필요하 다. 따라서 대부분의 경우에 이러한 무효전력의 전체 혹은 일 부를 유도발전기의 출력 측 커패시터 뱅크로 보상한다 ${ }^{(7)}$.

요구되는 무효전력을 통해 역률 보상용 커패시터 뱅크의 용량을 산정할 수 있으며, (3)을 통하여 구할수 있다.

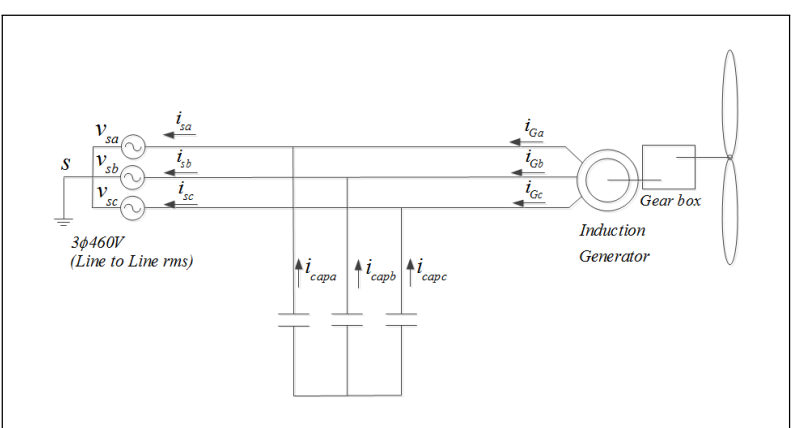

Fig. 2 Fixed speed-type wind power generation system with capacitor bank 
Table 1. Induction generator parameter

\begin{tabular}{l|c}
\hline \multicolumn{1}{|c|}{ 시스템 } & 값 \\
\hline 정격 용량 & $37.3 \mathrm{~kW}$ \\
\hline 정격 전압 & $460 \mathrm{~V}$ \\
\hline 정격 스피드 & $1705 \mathrm{RPM}$ \\
\hline 정격 토크 & $198 \mathrm{n} . \mathrm{mm}$ \\
\hline 고정자 저항 & $0.087 \Omega$ \\
\hline 고정자 인덕턴스 & $0.302 \Omega$ \\
\hline 자화 인덕턴스 & $13.08 \Omega$ \\
\hline 회전자 저항 & $0.228 \Omega$ \\
\hline 회전자 인덕턴스 & $0.302 \Omega$ \\
\hline 극수 & 4 극 \\
\hline 관성 모멘트 & $1.662 \mathrm{Kg} \cdot \mathrm{m}^{2}$ \\
\hline
\end{tabular}

$$
\begin{aligned}
& Q=V \times I=V \times \frac{V}{Z}=j \omega C V^{2} \\
& C=\frac{Q}{j \omega V^{2}}
\end{aligned}
$$

(3)을 통해 정해진 역률 보상용 커패시터 뱅크의 용량은 고 정적이다. 따라서, 기상의 변동에 따라 변동하는 무효전력의 보상범위가 한정적일 수 밖에 없다.

Table 1은 유도발전기의 파라미터이고, 유도발전기의 파 라미터는 참고문헌[8]를 참조하였다.

\subsection{Type1 모델과 STATCOM의 구성}

Table 2는 STATCOM의 파라미터로서 보상하려는 유도발 전시스템의 용량에 따라 산정되었다. Fig. 3은 고정 속도형 풍력발전기의 STATCOM 적용 회로이다. 역률 보상용 커패 시터 뱅크 대신에 STATCOM이 유도발전기의 여자전류에 의해 발생하는 무효전력을 즉각 보상한다. 이 때 계통전압과

Table 2. Circuit parameters in Fig. 3

\begin{tabular}{l|c}
\hline \multicolumn{1}{|c|}{ 시스템 } & 값 \\
\hline 정격 무효전력 용량 & $37.3 \mathrm{kVA}$ \\
\hline 정격 전압 & $460 \mathrm{~V}$ \\
\hline 인덕터(Ls) & $1.2 \mathrm{mH}$ \\
\hline 초기충전 저항 & $10 \Omega$ \\
\hline 전압 레퍼런스 $\mathrm{Vc}$ & $197 \mathrm{~V}$ \\
\hline 커패시터 & $9900 \mathrm{uF}$ \\
\hline 스위칭 주파수 & $1 \mathrm{kHz}$ \\
\hline
\end{tabular}

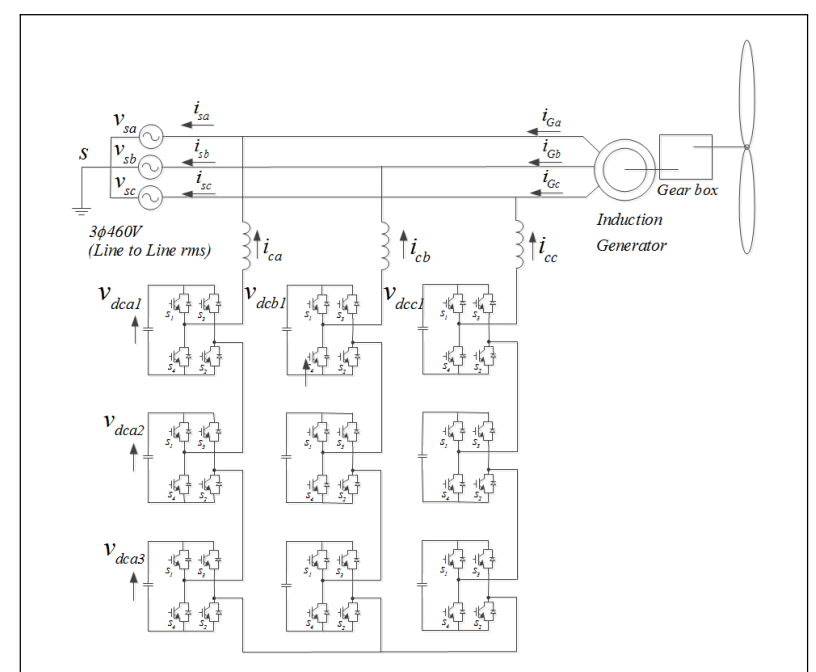

Fig. 3 Fixed speed-type wind power generation system with proposed star-configured Cascade H-bridge STATCOM

동상인 전류만을 계통으로 흐를 수 있도록 하여 유효전력만 을 발전하도록 보상한다.

\section{STATCOM 제어 블록도}

STATCOM은 1 개의 마스터와 9 개의 셀로 이루어져 있으 며, 단상 인버터들을 셀이라 명칭한다. Fig. 4는 STATCOM 의 제어블럭도로서, 전체적인 전압제어와 전류제어는 마스터 가 담당을 하며, $d-q$ 변환을 통해 제어된다. 전압제어에서 현 재 직류단의 값은 전체 셀의 직류단 전압값을 센싱하여 (4)와

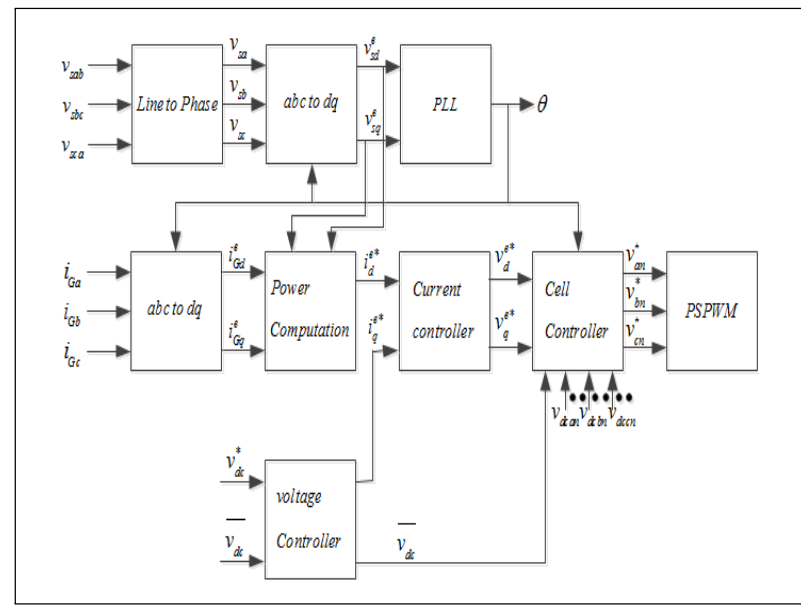

Fig. 4 Control block diagram for STATCOM 
같이 평균한다.

$$
\begin{aligned}
& v_{d c a}=\frac{1}{3} \sum_{n=1}^{3} v_{d c a n} \\
& \overline{v_{d c}}=\frac{1}{3}\left(v_{d c a}+v_{d c b}+v_{d c c}\right)
\end{aligned}
$$

(4)를 통하여 얻어진 직류단의 평균값을 전압레퍼런스와 비교하여 PI제어기를 통해 전압제어를 수행하고, 전류 제어 기의 출력은 마스터의 지령으로서 셀에 전달된다. 각각의 셀 은 전달된 지령을 PWM으로 출력한다. PLL(Phase Locked Loop)은 계통전압을 센싱받아 위상각을 추종하는 블록으로 서, 계통전압과 유도발전기 출력전류의 위상각으로부터 무효 전력을 계산하여 현재 발생하고 있는 무효전력을 보상하도록 한다. $d-q$ 변환에서의 유,무효 전력계산식은 식 (5)와 같다 ${ }^{(9)}$.

$$
\begin{aligned}
& p=v_{s d} \bullet i_{L d}+v_{s q} \cdot i_{L q}=v_{s q} \cdot i_{L q} \\
& q=v_{s q} \cdot i_{L d}-v_{s d} \cdot i_{L q}=v_{s q}
\end{aligned} i_{L d}
$$

$q$ 축을 유효분이며, d축은 무효분으로 변환하였다. 위 식을 통해 현재 무효전력을 계산하여 STATCOM이 현재 필요한 무 효전력을 보상하도록 한다. 이상적으로 무효전력만을 보상한 다고 하면 직류단 전압의 차이는 없어야 하나, 스위칭 손실이 각 셀마다 다르고, 커패시터의 용량이 제작시 부터 $\pm 10 \%$ 허 용오차가 존재하기 때문에 같은 에너지를 충전하고 방전하지 않는다. 위와 같은 이유로 각 셀에서는 같은 전압을 유지해줄 수 있는 제어가 필요하고 Cell controller가 이를 보상하여 $\mathrm{PWM}$ 지령을 주게된다. 셀의 전압 평형 제어 방법에 관해서 는 본 논문을 벗어나는 범위이므로 다루지 않도록 하겠다 ${ }^{(10)}$.

\section{5. 시뮬레이션 결과}

PSIM 시뮬레이션을 이용하여 기타 다른 조건들이 모두 동 등한 경우, 무효전력 변동 범위에 따라 역률 보상용 커패시터 뱅크와 STATCOM의 무효전력 보상 특성을 비교하였다. 무 효전력 변동의 범위는 여자전류에 의해 항시 발생하는 무효 전력을 보상하는 상황과 기상의 변동 혹은 사고 시에 발생하 는 무효전력이 증가하였을 경우 두가지 상황에 대해서 시뮬 레이션 하였다.
Fig. 5는 역률 보상용 커패시터 뱅크를 사용하였을 경우의 시뮬레이션을 위한 회로이다. 커패시터의 용량은 유도기의 무효전력 발생량을 보상하도록 (3)을 통하여 $225 \mathrm{uF}$ 으로 선 정하였다.

Fig. 6은 역률 보상용 커패시터 뱅크를 사용하여 여자전류 에 의해 항시 발생하는 무효전력을 보상한 결과파형이다. 계 산되어 정해진 역률 보상용 커패시터 뱅크가 무효전력 보상 한 후 계통으로 흐르는 전압과 전류의 zerocrossing point는 동상임을 확인할 수 있다.

Fig. 7은 기상의 변동으로 필요로 하는 무효전력이 $11 \mathrm{kVA}$ 로 증가한 경우의 시뮬레이션 결과 파형이다. 역률 보상용 커 패시터 뱅크를 사용하였기 때문에 무효전력이 증가하였음에

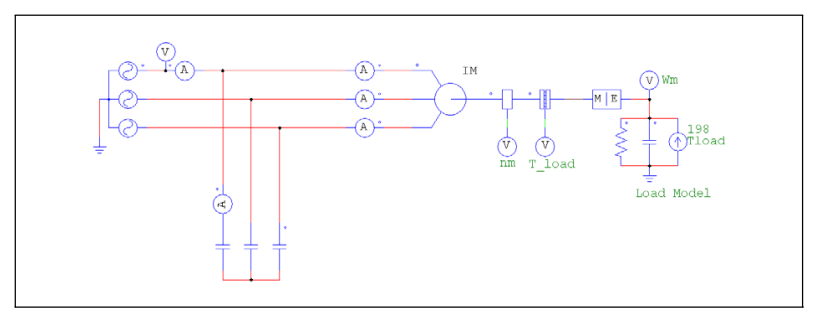

Fig. 5 Circuit configuration for simulation(Fixed capacitor)

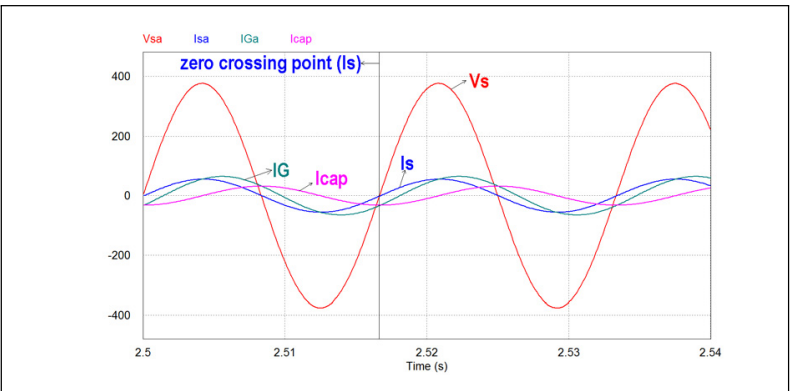

Fig. 6 Simulation result of Capacitor bank(reactive power : 648VA)

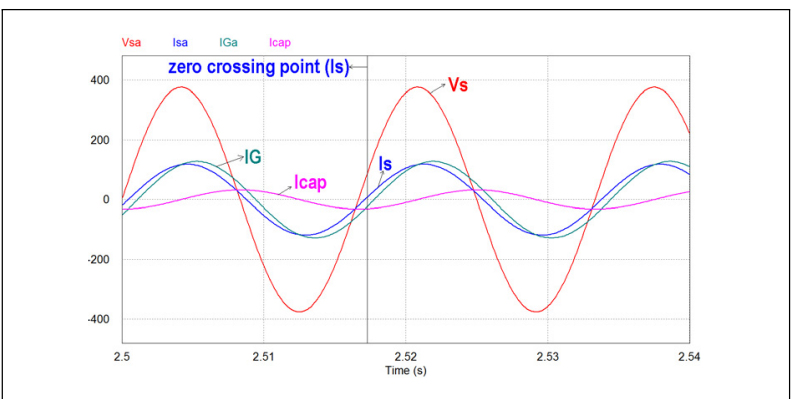

Fig. 7 Simulation result of Capacitor bank (increase reactive power: $11 \mathrm{kVA}$ ) 


\section{논문 2}

도 무효전력 보상의 범위는 Fig. 6과 동일하게 일정한 무효전 력만을 보상하는 것을 확인할 수 있다. 증가한만큼의 무효전 력을 역률 보상용 커패시터 뱅크가 감당하지 못하였기 때문 에 계통으로 흐르는 전류의 zero crossing point를 보면 계통 전압과 동상이 아닌 것을 확인할 수 있다.

Fig. 8은 STATCOM 시뮬레이션 회로도이다. STATCOM의 확장성을 확인하기 위해 상별로 3 개의 셀이 직렬로 연결하였 으며, 유도발전기의 출력과 계통사이의 지점 $\mathrm{PCC}$ (Point of Common Coupling)에서 여자전류에 의해 발생하는 무효전 력을 보상하도록 회로를 설계하였다. 전압레퍼런스는 셀별로 $197 \mathrm{~V}$ 를 유지하도록 하였고, $\mathrm{q}$ 축 전류는 스위칭 손실과 선로 임피던스에 의해 생기는 유효전력 손실을 보상하도록 제어하 였다.

Fig. 9는 여자전류에 의해 발생하는 무효전력을 보상한 시 뮬레이션 결과 파형이다. STATCOM은 무효전력을 정확히 보상하여 계통에 흐르는 전류의 zero crossing point가 계통

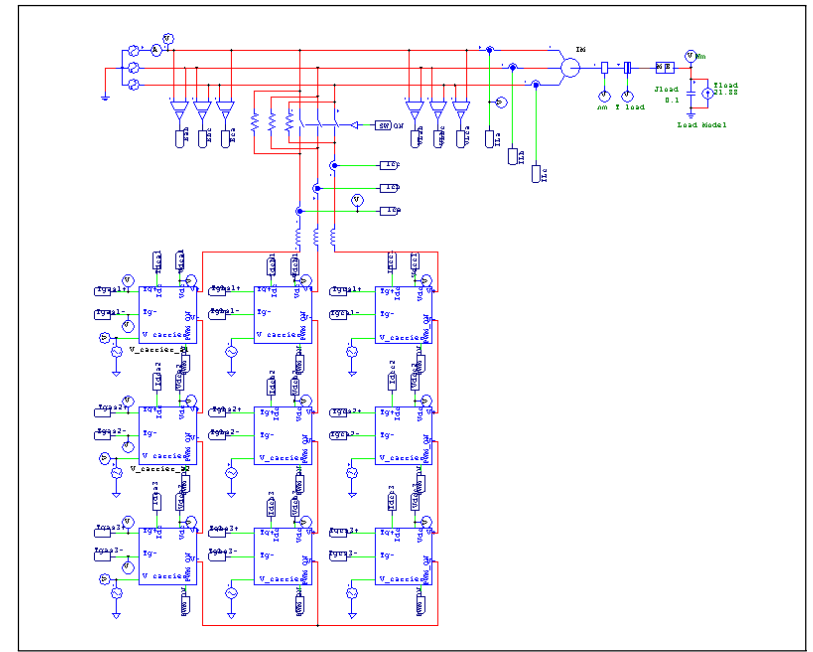

Fig. 8 Circuit configuration for simulation(STATCOM)

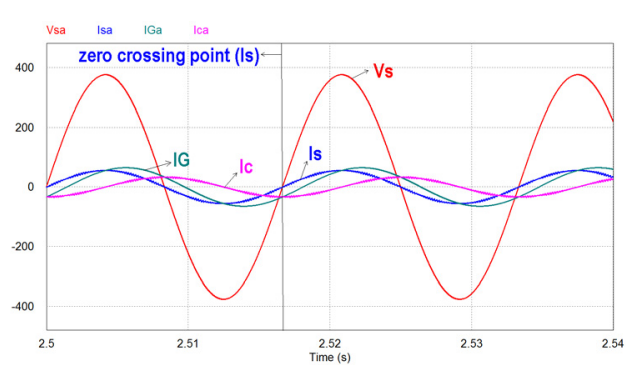

Fig. 9 Simulation result of STATCOM(reactive power: 648VA)
전압과 동상인 것을 확인할 수 있다.

Fig. 10은 동일하게 무효전력이 $11 \mathrm{kVA}$ 로 증가하였을 경우 의 시뮬레이션 결과 파형이다. 역률 보상용 커패시터 뱅크와 달리 무효전력이 증가하였을 경우 STATCOM에서 무효전력 의 증가량만큼을 정확히 보상하기 때문에 마찬가지로 계통전 압과 계통전류의 zero crossing point는 동상을 이룬다.

Fig. 11은 출력이 증가함에 따른 STATCOM의 과도상태 시 뮬레이션 결과파형이다. Fig. 11(a)는 출력이 2.1초까지 계속 적으로 증가하고 있는 과도상태에서도 STACOM이 무효전력 을 정확하게 보상하고 있어, 계통전압과 흐르는 전류는 동상 임을 확인할 수 있다. Fig. 11(b)는 동일한 조건의 과도상태

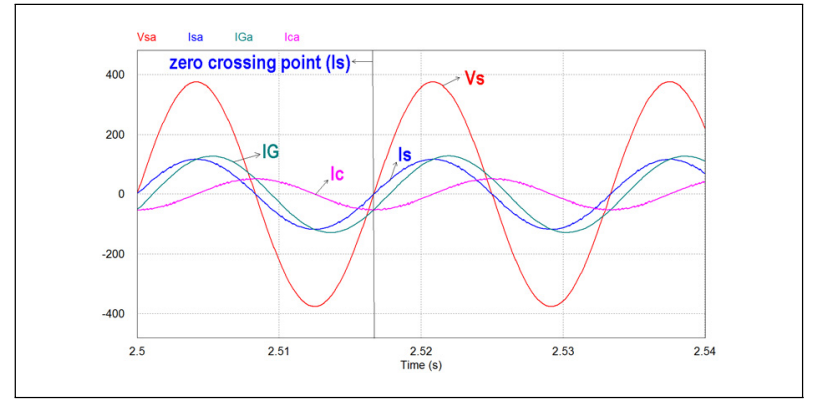

Fig. 10 Simulation result of STATCOM (increase reactive power: 11KVA)

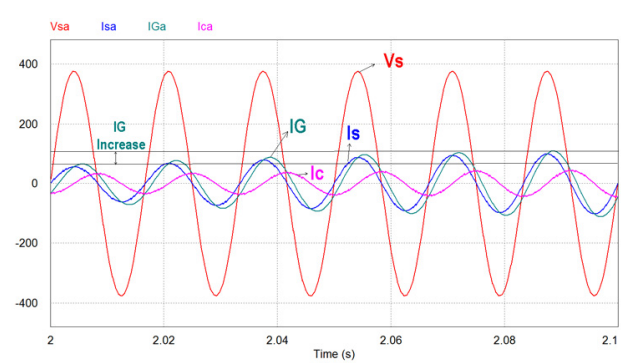

(a)

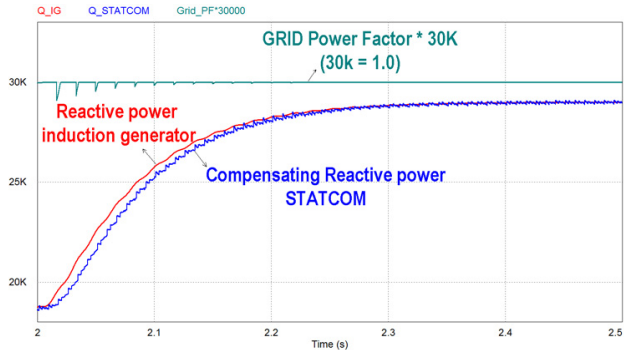

(b)

Fig. 11 Simulation result of STATCOM(transient state) 


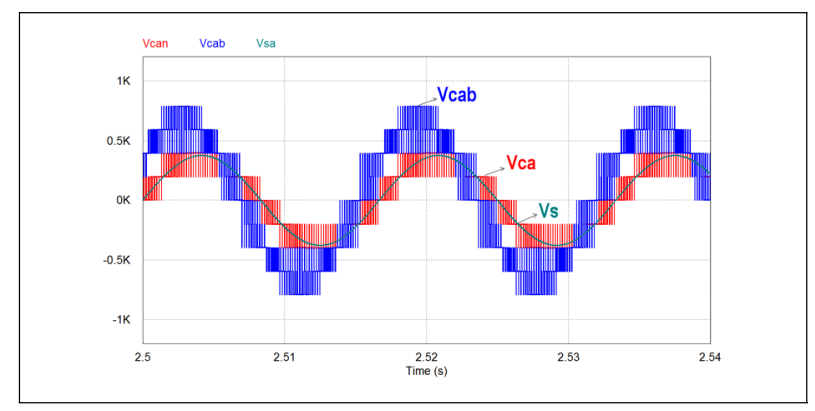

Fig. 12 Simulation result of STATCOM (output voltage STATCOM)

에서 무효전력을 비교한 결과파형으로서 2 초에서 2.5 초까지 무효전력이 증가하고, STATCOM에서는 증가된 무효전력량 만큼을 보상한다. 이때 계통에 흐르는 역률은 1.0 을 유지하는 것을 확인할 수 있다.

Fig. 12는 Cascade H-bridge STATCOM의 a상 출력파형 을 보여준다. 출력파형은 3 개의 셀이 직렬연결되어 있기 때 문에 상전압 출력은 7레벨의 출력파형이며, 선간출력 전압은 13 레벨의 출력파형을 확인할 수 있다. 계통전압과 상전압 출 력은 동상의 전압인 것을 확인할 수 있다.

\section{6. 결 론}

본 논문에서는 유도발전기를 사용한 고정 속도형 풍력발전 시스템의 출력 전력 품질 보상을 위해 새로운 멀티레벨 인버 터를 사용한 STATCOM을 제안하고 그 특성을 시뮬레이션 하 였다. 기존의 커패시터 뱅크방식에 비하여 과도상태 특성이 우수하고 연속적인 범위의 무효전력 보상이 가능한 것을 확 인하였다. 특히 최근에 강화되고 있는 국가별 그리드코드에 대응하기 위해서는 STATCOM 방식의 전력품질 보상기가 매 우 유용한 방식이 될 것으로 기대한다. 제안된 토폴로지 방식 의 STATCOM은 확장성이 우수하므로 대용량화가 용이하고 변압기를 사용하지 않으므로 부피나 가격면에서 유리한 반면 좀더 복잡한 제어 알고리즘을 필요로하는 특징이 있는데 이 는 앞으로 충분히 개선 발전되어 이러한 방식이 널리 활용될 수 있을 것으로 기대한다.

\section{후 기}

본 연구는 posco 연구과제인 Cascaded H-bridge multilevel STATCOM에서 DC-link 전압의 불평형 해석 및 제어 (과제번호 : 2012X023)의 지원으로 수행되었습니다.

\section{References}

[1] 송승호, 2011, "그리드코드 이해와 대응기술", 한국풍력에너 지학회 2011 추계 학술대회 Tutorial, pp. 1-27.

[2] 임지훈, 송승호, 2010, "계통 연계형 가변속 풍력발전기에서 정확한 무효전력 주입에 의한 PCC 전압 변동량 실시간 보 상”, 전력전자학회, Vol. 15, No. 1, pp. 69-74.

[3] Hagiwara, M, 2009, "Contol and Experiment of PulsewidthModulated Modular Multilevel Converters", IEEE Transactions on Power Electronics, Vol. 24, No. 7, pp. 1737-1746.

[4] Fujii, K, 2005, "A Novel DC-link Voltage Control of PWM-Switched Cascade Cell Multi-Level Inverter Applied to STATCOM”, Industry Applications Conference, Vol. 2, pp. 961-967.

[5] Rodriguez, J, 2002, "Multilevel inverters: a survey of topologies, controls, and applications", IEEE Transactions on Industrial Electronics, Vol. 49, No. 4, pp. 724-738.

[6] Young-Min Park, 2006, "A Simple and Reliable PWM Synchronization \& Phase-Shift Method for Cascaded $\mathrm{H}$-Bridge Multilevel Inverters based on a Standard Serial Communication Protocol”, IEEE Industry Applications conference, Vol. 2, pp. 988-994.

[7] 송승호, 2003, "풍력발전기의 전기적 특성과 계통연계시 상 호작용”, 전력전자학회, Vol. 8, No. 6, pp. 21-27.

[8] Krause, P.C. 1995, "Analysis of Electric Machinery", pp. 165, WILEY I-NTERSIENCE.

[9] Akagi, Hirofumi, 1984, "Instantaneous Reactive Power Compensators Comprising Switching Devices without Energy Storage Components", IEEE Transaction on Industry Applications, Vol. IA-20, No. 3, pp. 625-630.

[10] Akagi, Hirofumi, 2007, "Control and Performance of a Transformerless Cascade PWM STATCOM With Star Configuration", IEEE Transaction on Industry Applications, Vol. 43, No. 4, pp. 1041-1049. 


\section{김 지 홍}

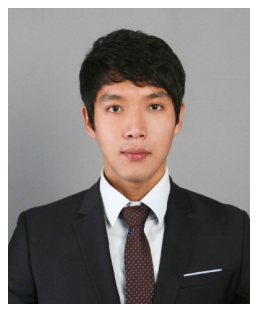

2011년 광운대학교 전기공학과 공학사

현재 광운대학교 전기공학부 석사과정

(E-mail : ranpoo@kw.ac.kr)

\section{송 승 호}

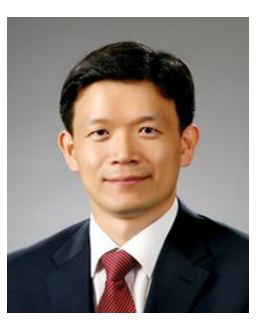

1991년 서울대학교 전기공학과 공학사

1993년 서울대학교 전기공학과 공학석사

1999년 서울대학교 전기공학과 공학박사
현재 광운대학교 전기공학과 교수

(E-mail : ssh@kw.ac.kr)

\section{정 승 기}

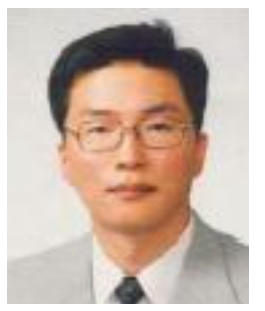

1982년 서울대학교 전기공학과 공학사 1984년 서울대학교 전기공학과 공학석사 1988년 서울대학교 전기공학과 공학박사

현재 광운대학교 전기공학과 교수

(E-mail : sgjeong@kw.ac.kr) 